\title{
Analysis of Pathotypes of Colletotrichum lindemuthianum Found in the Central Region of Mexico and Resistance in Elite Germ Plasm of Phaseolus vulgaris
}

\author{
Mario González-Chavira and Raúl Rodríguez Guerra, Instituto Nacional de Investigaciones Forestales, Agrícolas \\ y Pecuarias (INIFAP), Campo Experimental del Bajío, Celaya, Guanajuato, Mexico; Fernando Hernández- \\ Godínez, Department of Genetic Engineering, CINVESTAV, Unidad Irapuato, Apdo. Postal 629, Irapuato, Guana- \\ juato, Mexico; Jorge A. Acosta-Gallegos, Instituto Nacional de Investigaciones Forestales, Agrícolas y Pecuarias \\ (INIFAP), Campo Experimental del Bajío, Celaya, Guanajuato, Mexico; and Octavio Martínez de la Vega and June \\ Simpson, Department of Genetic Engineering, CINVESTAV, Unidad Irapuato, Apdo. Postal 629, Irapuato, \\ Guanajuato, Mexico
}

\begin{abstract}
González-Chavira, M., Rodríguez Guerra, R., Hernández-Godínez, F., Acosta-Gallegos, J. A., Martínez de la Vega, O., and Simpson, J. 2004. Analysis of pathotypes of Colletotrichum lindemuthianum found in the central region of Mexico and resistance in elite germ plasm of Phaseolus vulgaris. Plant Dis. 88:152-156.

The pathotypes of 17 isolates of Colletotrichum lindemuthianum from the central region of Mexico were characterized to determine the genetic relationship among isolates from this region and other regions of Mexico, and to evaluate the resistance present in the elite germ plasm collection of Phaseolus vulgaris at INIFAP. Eight pathotypes were identified, including pathotype 292, which is reported for the first time in Mexico. The lack of isolates infecting cultivar TU carrying the Co-5 resistance gene suggests that this cultivar is a useful source of resistance. Six pathotypes produced susceptible reactions on only differential cultivars of Middle American origin, one pathotype on a single cultivar of Andean origin, and one pathotype on cultivars of both Middle American and Andean origin. Comparison of amplified fragment length polymorphism (AFLP) genotypes of 21 isolates confirmed suggestions that populations of $C$. lindemuthianum are comprised of asexually reproducing clonal lineages. Analysis of five different pathotypes of $C$. lindemuthianum on 21 elite genotypes of $P$. vulgaris identified four genotypes from different races of $P$. vulgaris resistant to all five pathotypes. This information will allow breeders and farmers to select the resistant genotypes most suited to their needs.
\end{abstract}

Anthracnose of the common bean (Phaseolus vulgaris L.) caused by Colletotrichum lindemuthianum (Sacc. \& Magnus) Lams.-Scrib. is widespread throughout the world and can cause partial or total loss of susceptible crops when climatic conditions are favorable for the development of the pathogen (15). In Mexico, this disease occurs in all bean-producing regions with the exception of the Pacific Coast, where beans are cultivated under irrigated conditions during the dry period of the year. Diverse strategies have been recommended for the control of this disease (20); however, the best strategy is the use of resistant cultivars. To ensure that these cultivars are not infected by $C$. lindemuthianum, it is necessary to have knowledge of the fungal pathogen in bean-growing areas.

A set of 12 differential cultivars of $P$. vulgaris has been used to determine races

Corresponding author: June Simpson

E-mail: jsimpson@ira.cinvestav.mx

Accepted for publication 3 September 2003.

Publication no. D-2003-1124-02R

(C) 2004 The American Phytopathological Society or pathotypes of C. lindemuthianum. Four of these differential cultivars are of Andean origin and eight are of Middle American origin. In these materials, nine resistance genes have been identified, eight ( $\mathrm{Co}-\mathrm{I}$ to $\mathrm{Co}-7$ and $\mathrm{Co}-9)$ are dominant and one (co-8) is recessive. Only the Co- 1 resistance gene has been identified in Andean germ plasm (12), and the other eight resistance genes are found in Middle American germ plasm $(2,3,6,11,21,23)$. Another resistance gene, Co-10, has recently been described in the cultivar Ouro Negro (7), which is not included in the differential set.

Different studies carried out using the 12 differential cultivars have identified 111 pathotypes of $C$. lindemuthianum worldwide. Mexico is one of the countries where a high level of pathogenic diversity of $C$. lindemuthianum in both wild and cultivated germ plasm of $P$. vulgaris $(4,8,18)$ has been reported. Forty-one pathotypes have been identified in seven states in northern Mexico, with 448, 256, and 0 being the pathotypes most frequently reported. Of these, pathotype 448 has the widest geographical distribution (8). Characterization of isolates of $C$. lindemuthianum from the central and southern
Mexican states is necessary to obtain a more complete understanding of the diversity of this pathogen within the country.

Various sources of resistance to $C$. lindemuthianum in $P$. vulgaris have been identified $(14,17)$, and the differential cultivar G2333 was reported as one of the principal sources of resistance to this pathogen. Reports on the occurrence of pathotypes of $C$. lindemuthianum capable of overcoming the resistance of G2333 have stimulated the search for new sources of resistance, not only in distinct cultivars of $P$. vulgaris, but also in different species of the genus Phaseolus (10).

The bean improvement program of the Instituto Nacional de Investigaciones Forestales, Agrícolas y Pecuarias (National Research Institute for Forestry, Agriculture, and Animal Husbandry; INIFAP) has an elite collection of germ plasm of $P$. vulgaris that is used to develop new cultivars to meet the specific needs of Mexican farmers. These materials have been evaluated under different environmental conditions, and commercial cultivars, including some with resistance to $C$. lindemuthianum, have been released and have had a great impact on the production and commercialization of this legume $(1,9)$.

To date, identification and selection of germ plasm of $P$. vulgaris resistant to $C$. lindemuthianum in Mexico has been based mainly on the resistance of germ plasm under natural field conditions without previous knowledge of the pathotypes of C. lindemuthianum likely to be present in the bean producing regions.

Evaluation of the elite germ plasm collection for resistance to the specific pathotypes of $C$. lindemuthianum found in different regions of Mexico would be of great value for the development of cultivars of $P$. vulgaris with resistance genes adequate for the different regions and for the incorporation of a wider genetic spectrum of resistance to the pathogen (22).

The objectives of this research were to determine the pathotypes of isolates of $C$. lindemuthianum obtained in the central region of Mexico, to establish the genetic relationships among isolates from this 
region and isolates from other regions of Mexico, and to evaluate the resistance present in the INIFAP elite germ plasm collection of $P$. vulgaris to five contrasting pathotypes of $C$. lindemuthianum found in Mexico.

\section{MATERIALS AND METHODS}

Isolation of $C$. lindemuthianum and preparation of monoconidial cultures. Samples of pods, leaves, and/or stems from $P$. vulgaris plants with symptoms typical of anthracnose were collected between 1993 and 1996 in the states of Tlaxcala, Hidalgo, Mexico, and Puebla in the central region of Mexico (Fig. 1). Isolation and characterization of the pathotypes was carried out as described in González et al. (8). Diseased tissue (1 to $2 \mathrm{~mm}$ ) was placed on acidified $(200 \mu \mathrm{l}$ of lactic acid per liter) potato dextrose agar (PDA) medium (Difco Laboratories, Detroit, MI).

Hyphal tips from colonies with growth and morphology characteristics of C. lindemuthianum that developed from the diseased tissue were transferred to fresh culture media and incubated at $22^{\circ} \mathrm{C}$ until sporulation. One milliliter of water was applied to the area of the culture where sporulation had occurred in order to resuspend the conidia. Ten microliters of this suspension was then removed and added to $40 \mu \mathrm{l}$ of water. The $50-\mu \mathrm{l}$ suspension obtained was then plated on PDA medium. Individual, germinated conidia were recovered after $48 \mathrm{~h}$ of incubation and were transferred to fresh culture medium. Working stocks of the monoconidial cultures were maintained on PDA, and replicates were stored in agar and mineral oil at $4^{\circ} \mathrm{C}$.

Characterization of pathotypes of $\boldsymbol{C}$. lindemuthianum. In order to assign a pathotype to each isolate (13), 12 differential cultivars of $P$. vulgaris were used (Michelite, Michigan Dark Red Kidney, Perry Marrow, Cornell 49242, Widusa, Kaboon, Mexico 222, PI 207262, TO, TU, AB 136, G2333). A suspension of $1.5 \times 10^{6}$ conidia per $\mathrm{ml}$ was prepared from each isolate and was inoculated by aspersion onto the undersides of the primary leaves of three plantlets of each differential cultivar 7 to 10 days after emergence. Inoculated plants were incubated in a growth chamber at $95 \%$ relative humidity and $22^{\circ} \mathrm{C}$ under a photoperiod of $12 \mathrm{~h}$ light/dark. After 3 days, the plants were maintained at the same temperature and photoperiod at 86 to $90 \%$ relative humidity. Symptoms were evaluated 10 days after inoculation using the scale proposed by Garrido-Ramirez and Romero-Cova (5), where $0=$ no visible symptoms, $1=$ small necrotic lesions on veins on the underside of leaves, $2=$ larger necrotic lesions on veins and underside of leaves, 3 = large sporulating lesions, $4=$ widespread sporulating lesions and plant death. Values 0 to 2 are classed as resistant and 3 and 4 as susceptible. The experiment was conducted three times.

Amplified fragment length polymorphism (AFLP) and statistical analysis DNA was obtained from all isolates and subjected to AFLP analysis as described previously (8). Oligonucleotide primers used for the preamplification step were EcoRI (EcoRI+A) 5'-AGACTGCGTACCAATTC/A-3' and MseI (MseI+A) 5'-GACGATGAGTCCTGAGTAA/A-3'. The preamplification step was followed by a second selective amplification step using two selective nucleotides.

Data were analyzed as described in González et al. (8). Dendrograms were produced using the simple matching coefficient and the unweighted pair group method with arithmetic averages (UPGMA) using SAS 6.08 and S-plus 4.0 for Windows software (SAS Institute, Cary, NC).

Evaluation of elite germ plasm of $P$. vulgaris for resistance to five pathotypes of $\boldsymbol{C}$. lindemuthianum. Twenty-one genotypes, which included genotypes from the Durango, Jalisco, Nueva Granada, Mesoamerica, and Peru races of $P$. vulgaris and from both the Middle American and Andean gene pools, were selected for their importance in the INIFAP breeding programs (Table 1). These genotypes were evaluated for their reaction to pathotypes 0, 2, 292, 448, and 1472 of C. lindemuthianum. These pathotypes were selected on the basis of three criteria: (i) geographical distribution and frequency of occurrence in Mexico, (ii) degree of virulence, and (iii) gene pool (Andean or Middle American) of the differential cultivars they infect. Pathotype 2, supplied by James D. Kelly (Michigan State University), was recovered from the central region of Mexico and only infected the differential cultivar Michigan Dark Red Kidney of Andean origin.
Pathotype 292 was identified in the present study from the Isolate Mex 05 (Table 2 ). This isolate was chosen since it is a rare example in Mexico of a pathotype which infects differential cultivars from both Middle American and Andean gene pools. Pathotype 448 (CHI 01) (8) was selected because it is widespread within the regions of Mexico that have been sampled for $C$. lindemuthianum, it is common among characterized isolates, and it is a relatively virulent pathotype infecting 3 of the 12 differential cultivars. Pathotype 1472 (HGO 03) was also identified in the present work and was selected because it is one of the most virulent pathotypes identified in Mexico to date. Finally, pathotype 0 (JAL 07) (8) was selected because it does not infect any of the 12 differential cultivars but is nevertheless one of the three most frequently found pathotypes in Mexico.

Four plantlets of each differential cultivar were inoculated individually with the five pathotypes of $C$. lindemuthianum 7 to 12 days after emergence as described above. The experiment was conducted three times.

\section{RESULTS}

Characterization of pathotypes of $\boldsymbol{C}$. lindemuthianum. Twenty-one isolates of C. lindemuthianum were collected from four states in the central region of Mexico (Fig. 1). The pathotypes of 17 of these isolates were determined by inoculation on 12 differential cultivars of $P$. vulgaris. The pathotypes of the remaining four isolates could not be determined due to lack of sporulation or other technical difficulties. Eight distinct pathotypes were identified: three in isolates obtained in Mexico State (2, 292, and 448), four in Puebla (328, 384 , 448, and 449), two in Hidalgo (448 and 1472), and two in Tlaxcala (0 and 2).

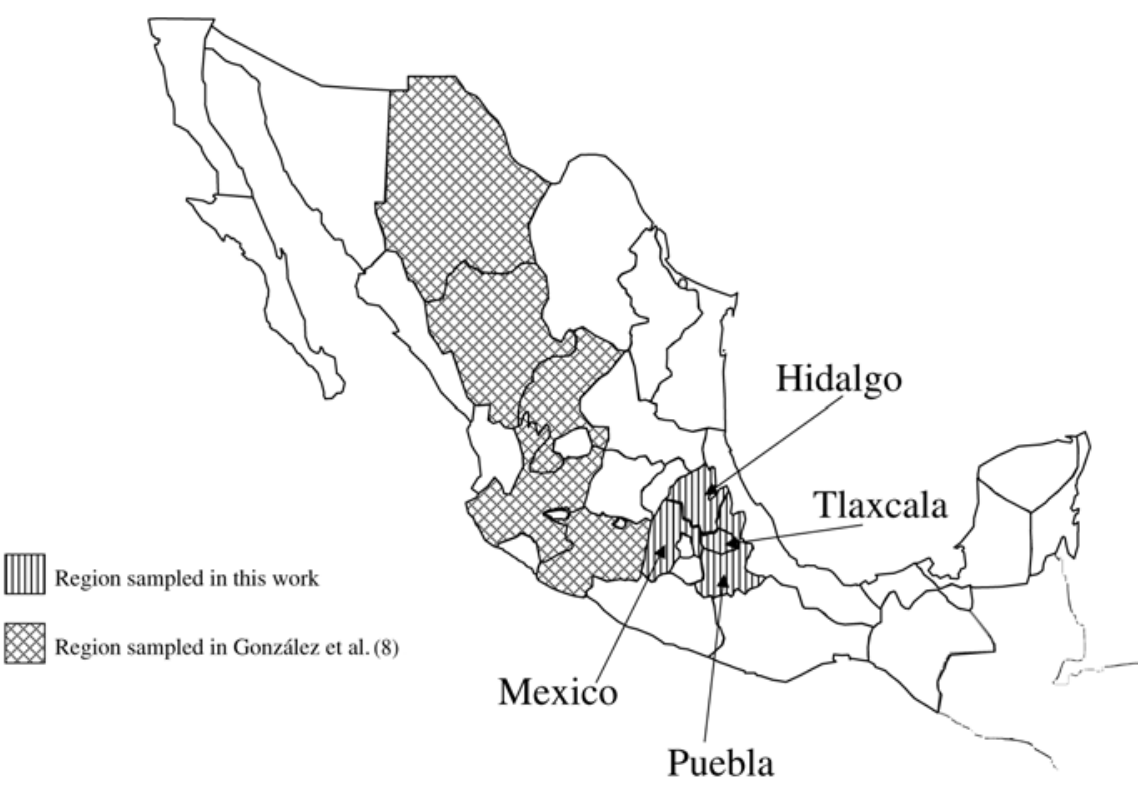

Fig. 1. Regions in Mexico where cultures of Colletotrichum lindemuthianum were obtained. 
Eight of the 17 isolates were pathotype 448 , and three isolates were pathotype 2 . The other six pathotypes were each represented by a single isolate. All pathotypes, except for pathotype 292, have been previously reported in Mexico.

Three types of pathogenic interaction were identified, in accordance with the genetic origin of the differential cultivars that were infected. Type 1 , shown by pathotype 2, infects only cultivar Michigan Dark Red Kidney from the Andean P. vulgaris gene pool. Type 2, shown by pathotypes $328,384,448,449$, and 1472, infects germ plasm of Middle American origin. Type 3, shown by pathotype 292, infects germ plasm of both gene pools of $P$. vulgaris.

Pathotypes 449 and 1472 were the most virulent isolates characterized, infecting 4 of the 12 differential cultivars, followed by pathotypes 292, 328, and 448, which infect 3 differential cultivars. Pathotypes 384 and 2 infect 2 and 1 differential cultivars, respectively. Pathotype 0 does not infect any of the differential cultivars.

AFLP and statistical analysis. The AFLP genotypes of the 21 isolates from Central Mexico were compared with other Mexican isolates of $C$. lindemuthianum (Fig. 2). The dendrogram showed that the isolates from Central Mexico form a distinct group within the dendrogram, which confirms the strong relationship between geographical origin and genotype observed in a previous study (8).

Evaluation of elite germ plasm of $P$. vulgaris for resistance to five pathotypes of $\boldsymbol{C}$. lindemuthianum. All of the elite genotypes analyzed were resistant to at least one of the pathotypes evaluated $(0,2$,
292, 448, and 1472) (Table 3). Based on the resistance/susceptibility reaction for each genotype, nine resistance groups could be identified. Group 1, containing materials from the Jalisco, Durango, Peru, and Middle American races of $P$. vulgaris, was resistant to all five $C$. lindemuthianum pathotypes. Group 2, containing materials of Middle American origin, was resistant to all pathotypes except 1472 . Group 3 comprises the improved cultivar Negro INIFAP of Middle American origin, which is resistant to all isolates except pathotype 292. Group 4 shows resistance to all iso- lates except pathotype 2 and contains two materials of $P$. vulgaris race Nueva Granada that are Andean in origin. Groups 5, 6, and 7 are each susceptible to two pathotypes, 448 and 1472, 292 and 1472, and 2 and 1472 , respectively. Group 8, formed by the improved cultivar ICA Palmar, is only resistant to pathotypes 0 and 448 , and group 9 , formed by Cacahuate 72 , is only resistant to pathotype 0 .

\section{DISCUSSION}

Eight pathotypes of $C$. lindemuthianum from a total of 17 isolates were identified

Table 2. Pathotypes of Colletotrichum lindemuthianum identified from the central region of Mexico

\begin{tabular}{ccl}
\hline $\begin{array}{l}\text { State } \\
\text { Isolate }\end{array}$ & Pathotype & Susceptible differential cultivars ${ }^{\mathbf{z}}$ \\
\hline Mexico & & \\
Mex 01 & 448 & Mexico 222, TO, PI207262 \\
Mex 02 & 2 & Michigan Dark Red Kidney \\
Mex 04 & 448 & Mexico 222, TO, PI207262 \\
Mex 05 & 292 & Perry Marrow, Kaboon, TO \\
Mex 06 & 448 & Mexico 222, TO, PI207262 \\
Mex 08 & 2 & Michigan Dark Red Kidney \\
Hidalgo & 448 & Mexico 222, TO, PI207262 \\
Hgo 02 & 1472 & Mexico 222, TO, PI207262, AB136 \\
Hgo 03 & & \\
Puebla & 448 & Mexico 222, TO, PI207262 \\
Pue 01 & 448 & Mexico 222, TO, PI207262 \\
Pue 02 & 328 & Mexico 222, TO, Cornell 49242 222, TO, PI207262 \\
Pue 03 & 448 & Mexico 222, TO, PI207262 \\
Pue 04 & 448 & PI207262, TO \\
Pue 05 & 384 & Mexico 222, TO, PI207262, Michelite \\
Pue 06 & 449 & Michigan Dark Red Kidney \\
Pue 07 & & None \\
Tlaxcala & 2 & \\
Tlax 01 & 0 & \\
Tlax 02 & & \\
\hline
\end{tabular}

z The complete set of differential cultivars used to determine pathotypes of $C$. lindemuthianum as described in (13) are Michelite, Michigan Dark Red Kidney, Perry Marrow, Cornell 49242, Widusa, Kaboon, Mexico 222, PI 207262, TO, TU, AB136, G2333.

Table 1. Characteristics of elite germ plasm of Phaseolus vulgaris from the National Research Institute for Forestry, Agriculture, and Animal Husbandry (INIFAP) in Mexico

\begin{tabular}{|c|c|c|c|c|c|c|}
\hline Genotype & $\operatorname{Race}^{\mathrm{x}}$ & $\begin{array}{l}\text { Growth } \\
\text { habit }^{y}\end{array}$ & Origin $^{z}$ & Type & Outstanding trait & Market class \\
\hline Amarillode Calpan & $\mathrm{J}$ & IIIb & Mex & Landrace & High yield potential & Yellow \\
\hline Bayo Mecentral & $\mathrm{J}$ & III & Mex & Improved cultivar & High yield potential & Cream \\
\hline Bayo Criollo del Llano & $\mathrm{D}$ & III & Mex & Landrace & Adaptation to low phosphate & Cream \\
\hline Bola 60 días & NG & I & $\mathrm{Ecu}$ & Landrace & Earliness/rust resistance & Canario \\
\hline Cacahuate 72 & NG & I & Mex & Improved cultivar & Earliness/rust resistance & Cranberry \\
\hline Canario 107 & NG & I & Mex & Landrace & Earliness/rust resistance & Canario \\
\hline EPRI 20 & NG & I & Mex & Improved line & High yield potential & Sulfur \\
\hline Flor de Mayo 94006 & $\mathrm{~J}$ & III & Mex & Improved line & High yield potential & Cream with pink spots \\
\hline Flor de Mayo 2000 & $\mathrm{~J}$ & III & Mex & Improved cultivar & High yield potential & Cream with pink spots \\
\hline G17717 & $\mathrm{P}$ & II & Peru & Improved line & Erect architecture & Mauve/cream lines \\
\hline G19428 & $\mathrm{P}$ & II & Peru & Improved line & Erect architecture & Cream \\
\hline ICA Palmar & NG & I & Col & Improved cultivar & Drought resistance & Red mottled \\
\hline MAM 48 & $\mathrm{D}$ & III & $\mathrm{Col}$ & Improved line & High yield potential & Pinto \\
\hline México 332 & $\mathrm{~J}$ & IIIb & Mex & Landrace & High yield potential & Shiny black \\
\hline Negro INIFAP & M & II & Mex & Improved cultivar & High yield potential & Opaque black \\
\hline Negro TACANA & M & II & Mex & Improved cultivar & High yield potential & Opaque black \\
\hline Pinto Villa & $\mathrm{D}$ & III & Mex & Improved cultivar & Drought resistance & Pinto \\
\hline Pinto Zapata & $\mathrm{D}$ & II & Mex & Improved line & Drought resistance & Pinto \\
\hline TLP 19 & M & II & Col & Improved line & Adaptation to low phosphate & Opaque black \\
\hline TLP 20 & M & II & $\mathrm{Col}$ & Improved line & Adaptation to low phosphate & Opaque black \\
\hline Negro 8025 & M & III & Mex & Improved cultivar & High yield potential & Opaque black \\
\hline
\end{tabular}

${ }^{x}$ Races determined according to Singh et al. (19): J = Jalisco, D = Durango, NG = Nueva Granada, P = Peru, M = Mesoamerican.

${ }^{y}$ Growth habits: I = determinate; II = indeterminate bush type with erect stems and branches; III = indeterminate bush type with weak stems and branches; $\mathrm{IIIb}=$ indeterminate bush type with weak stems and branches, long leading shoots and climbing capacity.

${ }^{\mathrm{z}}$ Country of origin: $\mathrm{Mex}=$ Mexico, Ecu $=$ Ecuador, $\mathrm{Col}=$ Colombia. 
in the central region of Mexico comprising the states of Mexico, Tlaxcala, Puebla, and Hidalgo. The level of pathogenic variability is higher in these isolates than that observed previously. In the study of González et al. (8), 10 pathotypes were identified in 59 isolates from five states, and Sicard et al. (18) described 11 pathotypes in 50 isolates from five states. Although Balardin et al. (4) identified 22 pathotypes in 44 isolates, the geographical distribution of these isolates was not reported. The high level of pathogenic variation in the central region may be due to the diverse germ plasm of $P$. vulgaris grown in this region, where climbing and bush type landraces are mainly grown. This contrasts with other regions where improved bush type cultivars are grown in monoculture or climbing type landraces are grown in combination with maize.

The pathotypes identified confirm the observations of González et al. (8) that the majority of isolates of $C$. lindemuthianum found in Mexico infect Middle American germ plasm of $P$. vulgaris. Two pathotypes identified in the central region (2 and 292) do not adhere to this. Pathotype 2 infects a single differential cultivar from the Andean gene pool (Michigan Dark Red Kidney) known to carry the Co- 1 anthracnose resistance gene. Pathotype 292 is unusual because it is capable of infecting cultivars from both Middle American and Andean gene pools of $P$. vulgaris. The occurrence of such pathotypes is rare in Mexico. In total, 76 isolates of $C$. lindemuthianum from different regions of Mexico have been analyzed by our group, and this is the first isolate that is capable of infecting germ plasm from both gene pools. Sicard et al. (18) reported 1 isolate in 50 and Balardin et al. (4) reported 7 in 44 that infect germ plasm in both gene pools.

Pathotype 0, which does not infect any of the 12 standard differential cultivars, has been reported previously in Mexico $(8,18)$. These isolates are capable of infecting other cultivars, such as La Victoire and Flor de Mayo Bajío (P. Neponuceno and J.. Simpson, personal communication), suggesting that the differential cultivar set should be extended to include at least one of these.

In this study, isolates capable of infecting the differential TU, which carries the $\mathrm{Co}-5$ gene, were not identified. Such pathotypes are extremely rare in Mexico. In a previous study, González et al. (8) did not find any pathotypes infecting TU in 59 isolates, and Sicard et al. (18) also found none in 50 isolates. Balardin et al. (4) found only 2 isolates that infected TU. from a total of 44 . This suggests that wider incorporation of germ plasm carrying $\mathrm{Co}-5$ in breeding programs in Mexico could be successful in generating resistant cultivars.

Analysis of the AFLP genotypes of the isolates and comparison with other Mexican isolates shows that they form a discrete group within the dendrogram, and isolates that are geographically closer are also genotypically closer. This confirms our hypothesis that the populations of $C$. lindemuthianum in Mexico comprise clonal lineages formed by asexual reproduction.

The reactions of the 21 elite genotypes of $P$. vulgaris to the five pathotypes of $C$. lindemuthianum tested provide valuable information for breeders and farmers. Four of the materials, each from a different race of $P$. vulgaris and including one Andean

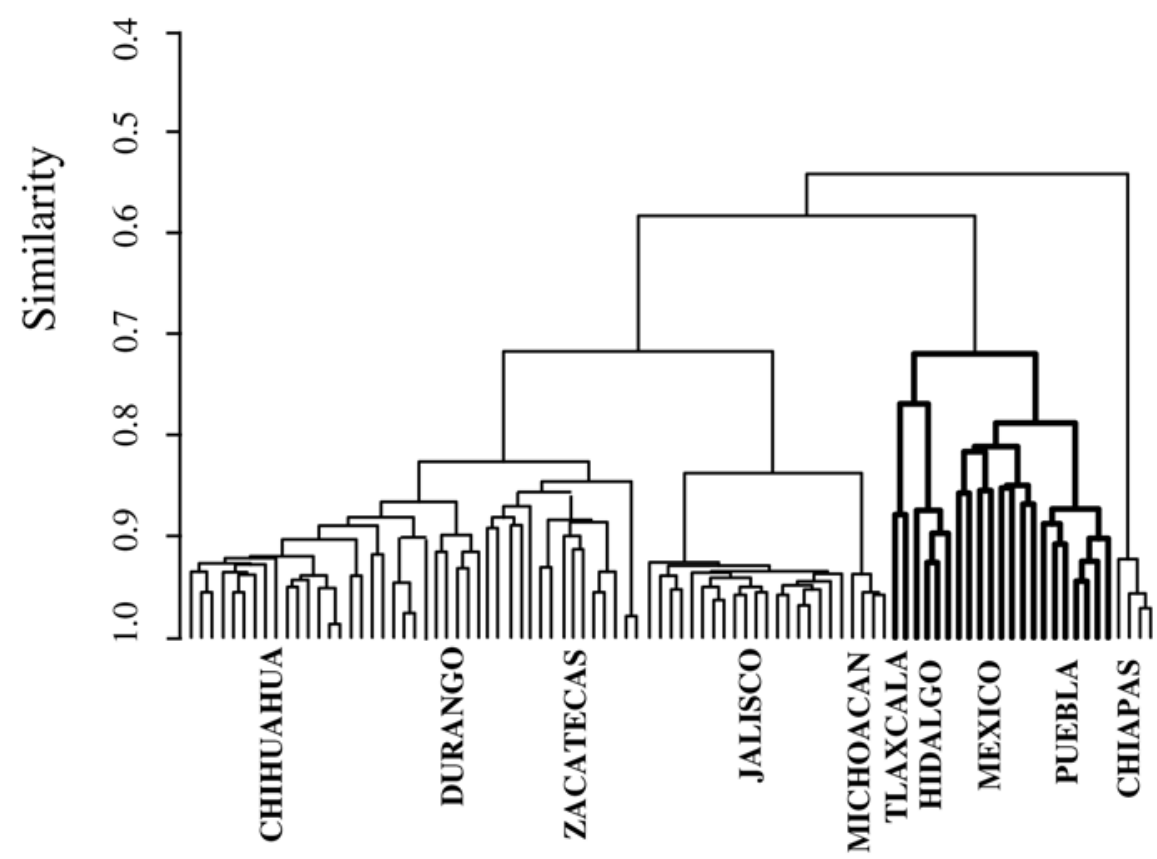

Fig. 2. Dendrogram comparing amplified fragment length polymorphism (AFLP) genotypes of isolates of Colletotrichum lindemuthianum from the central region with isolates from other regions of Mexico. Thick lines show isolates from the central region. Results from Chihuahua, Durango, Zacatecas, Jalisco, and Michoacán were previously published by González et al. (8).

Table 3. Reactions of elite germ plasm collection of Phaseolus vulgaris from the National Research Institute for Forestry, Agriculture, and Animal Husbandry (INIFAP) in Mexico to five pathotypes of Colletotrichum lindemuthianum

\begin{tabular}{|c|c|c|c|c|c|c|}
\hline \multirow{2}{*}{$\begin{array}{l}\begin{array}{l}\text { Genotypes of } \boldsymbol{P} \text {. vulgaris } \\
\text { (gene pool/race) }^{\mathbf{z}}\end{array} \\
\text { Bayo Mecentral (M/J) }\end{array}$} & \multicolumn{5}{|c|}{ Pathotypes } & \multirow{2}{*}{$\frac{\text { Resistance groups }}{1}$} \\
\hline & $\mathrm{R}$ & $\mathrm{R}$ & $\mathrm{R}$ & $\mathrm{R}$ & $\mathrm{R}$ & \\
\hline G19428 (A/P) & $\mathrm{R}$ & $\mathrm{R}$ & $\mathrm{R}$ & $\mathrm{R}$ & $\mathrm{R}$ & 1 \\
\hline Pinto Villa (M/D) & $\mathrm{R}$ & $\mathrm{R}$ & $\mathrm{R}$ & $\mathrm{R}$ & $\mathrm{R}$ & 1 \\
\hline TLP 19 (M/Mes) & $\mathrm{R}$ & $\mathrm{R}$ & $\mathrm{R}$ & $\mathrm{R}$ & $\mathrm{R}$ & 1 \\
\hline Bayo Criollo del LLano (M/D) & $\mathrm{R}$ & $\mathrm{R}$ & $\mathrm{R}$ & $\mathrm{R}$ & $\mathrm{S}$ & 2 \\
\hline Flor de Mayo $2000(\mathrm{M} / \mathrm{J})$ & $\mathrm{R}$ & $\mathrm{R}$ & $\mathrm{R}$ & $\mathrm{R}$ & $\mathrm{S}$ & 2 \\
\hline Pinto Zapata (M/D) & $\mathrm{R}$ & $\mathrm{R}$ & $\mathrm{R}$ & $\mathrm{R}$ & $\mathrm{S}$ & 2 \\
\hline TLP 20 (M/Mes) & $\mathrm{R}$ & $\mathrm{R}$ & $\mathrm{R}$ & $\mathrm{R}$ & $\mathrm{S}$ & 2 \\
\hline Negro 8025 (M/Mes) & $\mathrm{R}$ & $\mathrm{R}$ & $\mathrm{R}$ & $\mathrm{R}$ & $\mathrm{S}$ & 2 \\
\hline N. INIFAP (M/Mes) & $\mathrm{R}$ & $\mathrm{R}$ & $\mathrm{S}$ & $\mathrm{R}$ & $\mathrm{R}$ & 3 \\
\hline Bola 60 días (A/NG) & $\mathrm{R}$ & $\mathrm{S}$ & $\mathrm{R}$ & $\mathrm{R}$ & $\mathrm{R}$ & 4 \\
\hline Canario 107 (A/NG) & $\mathrm{R}$ & $\mathrm{S}$ & $\mathrm{R}$ & $\mathrm{R}$ & $\mathrm{R}$ & 4 \\
\hline Amarillo de Calpan (M/J) & $\mathrm{R}$ & $\mathrm{R}$ & $\mathrm{R}$ & $\mathrm{S}$ & $\mathrm{S}$ & 5 \\
\hline Flor de Mayo $94006(\mathrm{M} / \mathrm{J})$ & $\mathrm{R}$ & $\mathrm{R}$ & $\mathrm{R}$ & $\mathrm{S}$ & $\mathrm{S}$ & 5 \\
\hline G17717 (A/P) & $\mathrm{R}$ & $\mathrm{R}$ & $\mathrm{S}$ & $\mathrm{R}$ & $\mathrm{S}$ & 6 \\
\hline MAM 48 (M/D) & $\mathrm{R}$ & $\mathrm{R}$ & $\mathrm{S}$ & $\mathrm{R}$ & $\mathrm{S}$ & 6 \\
\hline México 332 (M/J) & $\mathrm{R}$ & $\mathrm{R}$ & $\mathrm{S}$ & $\mathrm{R}$ & $\mathrm{S}$ & 6 \\
\hline N. Tacaná (M/Mes) & $\mathrm{R}$ & $\mathrm{R}$ & $\mathrm{S}$ & $\mathrm{R}$ & $\mathrm{S}$ & 6 \\
\hline EPRI 20 (A/NG) & $\mathrm{R}$ & $\mathrm{S}$ & $\mathrm{R}$ & $\mathrm{R}$ & $\mathrm{S}$ & 7 \\
\hline ICA Palmar (A/NG) & $\mathrm{R}$ & $\mathrm{S}$ & $\mathrm{S}$ & $\mathrm{R}$ & $\mathrm{S}$ & 8 \\
\hline Cacahuate $72(\mathrm{~A} / \mathrm{NG})$ & $\mathrm{R}$ & $\mathrm{S}$ & $\mathrm{S}$ & $\mathrm{S}$ & $\mathrm{S}$ & 9 \\
\hline
\end{tabular}

${ }^{\mathrm{z}}$ Gene pool: $\mathrm{A}=$ Andean, $\mathrm{M}=$ Middle American, Mes = Race Mesoamerica. Race: NG = Race Nueva Granada, $\mathrm{J}=$ Race Jalisco, D = Race Durango, $\mathrm{P}=$ Race Peru. and three Middle American genotypes, wed resistance to all five pathotypes of contrasting materials showed resistance to all five pathotypes will allow breeders to choose a genotype most suitable to their needs in a breeding program. The reactions resistant to all pathotypes, will allow to take into account possible weaknesses in resistance in genotypes that have other useful characteristics. 
This report extends our knowledge of pathotypes of $C$. lindemuthianum and population structure in Mexico. In general, the pathotypes identified infect Middle American germ plasm, although some rare pathotypes that infect material from the Andean gene pool or from both gene pools can be found. As observed previously (8), the populations of $C$. lindemuthianum seem to be clonal lineages produced by asexual reproduction. Rodríguez-Guerra et al. (16) have shown that anastomosis and parasexualism may be a source of variation in $C$. lindemuthianum in such populations in the field.

The reactions of the elite genotypes of $P$. vulgaris to the five pathotypes of $C$. lindemuthianum provide important information for breeders and farmers and highlight $\mathrm{Co}-5$ as a useful source of resistance in Mexico. Elite materials resistant to all five pathotypes should be tested with pathotypes of $C$. lindemuthianum lacking Avr-Co-2, Avr-Co-5, and Avr Co-10 in order to determine whether resistance to the five pathotypes tested is provided by the $\mathrm{Co}-5, \mathrm{Co}-2$, or Co-10 resistance genes of $P$. vulgaris.

Further analysis of Andean P. vulgaris genotypes, and in particular of race Peru, is necessary in order to characterize new sources of resistance in these materials.

\section{ACKNOWLEDGMENTS}

We are grateful to Luis Herrera for critical reading of the manuscript, to Delphine Sicard for access to her Ph.D. thesis, and to James D. Kelly for helpful discussions and the kind gift of $C$. lindemuthianum race 2 . We are also indebted to CONACyT, Mexico, for financial support under grants $3218 \mathrm{~N}$ and $28275 \mathrm{SIM}$, and to the EEC for grant CT1*-CT94-0074.

\section{LITERATURE CITED}

1. Acosta-Gallegos, J. A., Ochoa Márquez, R., Arrieta Montiel, M. P., Ibarra Pérez, F., Pajarito Ravelero, A., and Sánchez Valdéz, Y. 1995. Registration of "Pinto Villa" common bean. Crop Sci. 35:1211.

2. Alzate-Marin, A. L., Baía, G. S., de Paula
Júnior, T. J., de Carvalho, G. A., de Barros, E. G., and Moreira, M. A. 1997. Inheritance of anthracnose resistance in common bean differential cultivar AB 136. Plant Dis. 81:996-998.

3. Alzate-Marin, A. L., Costa, M. R., Arruda, K. M., de Barros, E. G., and Moreira, M. A. Characterization of the anthracnose resistance gene present in Ouro Negro (Honduras 35) common bean cultivar. Euphytica In press.

4. Balardin, R. S., Jarosz, A. M., and Kelly, J. D. 1997. Virulence and molecular diversity in Colletotrichum lindemuthianum from South, Central, and North America. Phytopathology 87:1184-1191.

5. Garrido-Ramirez, E. R., and Romero-Cova, S. 1989. Identificación de razas de Colletotrichum lindemuthianum (Sacc. Y Magn.) Scrib. en México y búsqueda de resistencia genética a este hongo. Agrociencia 77:139156.

6. Geffroy, V., Sicard, D., de Oliveira, J. C. F., Sevignac, M., Cohen, S., Gepts, P., Neema, C., Langin, T., and Dron, M. 1999. Identification of an ancestral resistance gene cluster involved in the coevolution process between Phaseolus vulgaris and its fungal pathogen Colletotrichum lindemuthianum. Mol. Plant-Microbe Interact. 12:774-784.

7. Goncalves-Vidigal, M. C., Vallejo, V., and Kelly, J. 2003. Characterization of the anthracnose resistance in the differential cultivar Widusa. Annu. Rep. Bean Improv. Coop. 46:175-176.

8. González, M., Rodríguez, R., Zavala, M. E., Jacobo, J. L., Hernández, F., Acosta, J., Martínez, O., and Simpson, J. 1998. Characterization of Mexican isolates of Colletotrichum lindemuthianum by using differential cultivars and molecular markers. Phytopathology 88:292-299.

9. López Salinas, E., Acosta Gallegos, J. A., Frayre Vázquez, G., Orozco, S. H., and Beebe, S. E. 1997. Registration of 'Negro Tacana' common bean. Crop Sci. 37:1022.

10. Mahuku, G. S., Jara, C. E., Cajiao, C., and Beebe, S. 2002. Sources of resistance to Colletotrichum lindemuthianum in the secondary gene pool of Phaseolus vulgaris and in crosses of primary and secondary gene pools. Plant Dis. 86:1383-1387.

11. Melotto, M., and Kelly, J. D. 2000. An allelic series at the $\mathrm{Co}-1$ locus conditioning resistance to anthracnose in common bean of Andean origin. Euphytica 116:143-149.

12. Mendoza, A., Hernández, F., Hernández, S., Ruiz, D., Martínez de la Vega, O., Mora, G.,
Acosta, J., and Simpson, J. 2001. Identification of $\mathrm{Co}-1$ anthracnose resistance and linked molecular markers in common bean line A193. Plant Dis. 85:252-255.

13. Pastor-Corrales, M. A. 1991. Estandarización de variedades diferenciales y de designación de razas de Colletotrichum lindemuthianum. (Abstr.) Phytopathology 81:694.

14. Pastor-Corrales, M. A., Otoya, M. M., Molina, A., and Singh, S. P. 1995. Resistance to Colletotrichum lindemuthianum isolates from Middle América and Andean South America in different common bean races. Plant Dis. 79:63-67.

15. Pastor-Corrales, M. A., and Tu, J. C. 1989. Anthracnose. Pages 77-104 in: Bean Production Problems in the Tropics. H. F. Schwartz and M. A. Pastor-Corrales, eds. Centro Internacional de Agricultura Tropical, Cali, Colombia.

16. Rodríguez-Guerra, R., Ramírez-Rueda, M.-T., Martínez de la Vega, O., and Simpson, J. 2003 Variation in genotype, pathotype and anastomosis groups of Colletotrichum lindemuthianum isolates from Mexico. Plant Pathol. 52:228-235

17. Schwartz, H. F., Pastor-Corrales, M. A., and Singh, S. P. 1982. New sources of resistance to anthracnose and angular leaf spot of beans (Phaseolus vulgaris L.). Euphytica 31:741754.

18. Sicard, D., Michalakis, Y., Dron, M., and Neema, C. 1997. Genetic diversity and pathogenic variation of Colletotrichum lindemuthianum in the three centers of diversity of its host, Phaseolus vulgaris. Phytopathology 87:807-813.

19. Singh, S. P., Gepts, P., and Debouck, D. G. 1991. Races of common bean (Phaseolus vulgaris, Fabaceae) Econ. Bot. 45:379-396.

20. Tu, J. C. 1988. Control of bean anthracnose caused by the delta and lambda races of Colletotrichum lindemuthianum in Canada. Plant Dis. 72:5-8.

21. Young, R. A., and Kelly, J. D. 1996. Characterization of the genetic resistance to Colletotrichum lindemuthianum in common bean differential cultivars. Plant Dis. 80:650-654.

22. Young, R. A., and Kelly, J. D. 1996. Gene pyramiding using marker assisted selection for stable resistance to bean anthracnose. Annu. Rep. Bean Improv. Coop. 39:57-58.

23. Young, R. A., Melotto, M., Nodari, R. O., and Kelly, J. D. 1998. Marker assisted dissection of oligogenic anthracnose resistance in the common bean cultivar, G2333. Theor. Appl. Genet. 96:87-94. 